\title{
PENERAPAN MODEL THINK TALK WRITE UNTUK MENINGKATKAN KETERAMPILAN MENULIS KALIMAT EFEKTIF SISWA SEKOLAH DASAR
}

\author{
Erlina Sari ${ }^{1}$, Iis Aprinawati ${ }^{2}$, Rizki Ananda ${ }^{3}$ \\ (Pendidikan Guru Sekolah Dasar, Universitas Pahlawan Tuanku Tambusai, Indonesia)
}

E-mail: ${ }_{1}^{1}$ sarierlina411@gmail.com, ${ }^{2}$ aprinawatiiis@gmail.com, ${ }^{3}$ rizkiananda@universitaspahlawan.ac.id

\begin{tabular}{|l|l|l|}
\hline Receive: 13/05/2021 & Accepted: 23/08/2021 & Published: 01/10/2021
\end{tabular}

\begin{abstract}
Abstrak
Penelitian ini dilatar belakangi oleh rendahnya keterampilan menulis kalimat efektif pada pembelajaran tematik kelas III SDN 005 Padang Luas Kecamatan Tambang Kabupaten Kampar. Salah satu solusi untuk mengatasi masalah ini adalah dengan penerapan model Think Talk Write (TTW). Tujuan penelitian ini untuk meningkatkan keterampilan menulis kalimat efektif pada siswa kelas III SDN 005 Padang Luas. Metode Penelitian ini adalah penelitian tindakan kelas (PTK) yang dilaksanakan dalam dua siklus. Setiap siklus terdiri dari dua pertemuan dan empat tahap yaitu tahap perencanaan, pelaksanaan, observasi, dan refleksi. Waktu penelitian dilaksanakan Juni 2021. Subjek penelitian ini siswa kelas III yang berjumlah sebanyak 17 siswa dengan jumlah laki-laki 9 siswa dan perempuan berjumlah 8 siswa. Teknik pengumpulan data yaitu tes, observasi, dokumentasi. Hasil penelitian ini dapat disimpulkan bahwa pada siklus I tergolong baik dengan ratarata 67,82, selanjutnya dari 17 siswa hanya 8 siswa yang tuntas dan ketuntasan secara klasikal 47,05\%. Pada siklus II sangat baik dengan rata-rata 77,47 kemudian dari 17 siswa terdapat 14 siswa yang tuntas dan untuk ketuntasan secara klasikal 82,35\%. Dengan demikian dapat disimpulkan bahwa dengan penerapan model Think Talk Write (TTW) dapat meningkatkan keterampilan menulis kalimat efektif pada kelas III SDN 005 Padang Luas.
\end{abstract}

Kata kunci : Model Think Talk Write (TTW), keterampilan menulis, kalimat efektif, siswa

Sekolah Dasar

\begin{abstract}
This research was motivated by the low skill of writing effective sentences in the third grade thematic learning at SDN 005 Padang Luas, Tambang District, Kampar Regency. One solution to overcome this problem is to apply themodel Think Talk Write. The purpose of this study was to improve effective sentence writing skills in third grade students of SDN 005 Padang Luas. This research method is classroom action research which is carried out in two cycles. The subjects of this research were class III students, totaling 17 students with 9 male students and 8 female students. Data collection techniques are tests, observations, documentation. The results of this study can be concluded that in the first cycle is classified as good with an average of 67.82, then out of 17 students only 8 students completed and classical completeness $47.05 \%$. In cycle II it was very good with an average of 77.47 then from 17 students there were 14 students who completed and for classical completeness $82.35 \%$. Thus, it can be concluded that the application of themodel Think Talk Write (TTW) can improve effective sentence writing skills in class III SDN 005 Padang Luas.
\end{abstract}

Keywords: Model Think Talk Write (TTW), writing skills, effective sentences, Elementary School Students 


\section{Pendahuluan}

Pembelajaran tematik dilaksanakan dengan menggunakan prinsip pembelajaran terpadu. Pembelajaran terpadu menggunakan tema sebagai pemersatu kegiatan pembelajaran yang memadukan beberapa mata pelajaran sekaligus dalam satu kali tatap muka, untuk memberikan pengalaman yang bermakna bagi peserta didik (Kemendikbud, 2013). Pembelajaran tematik meliputi berbagai mata pelajaran salah satunya yaitu Bahasa Indonesia. Pembelajaran Bahasa Indonesia di Sekolah Dasar mempunyai kedudukan yang penting, Tarigan (2013) berpendapat, "tujuan pembelajaran Bahasa Indonesia di Sekolah Dasar yaitu agar siswa mempunyai keterampilan berbahasa, semakin terampil seseorang berbahasa, maka semakin cerah dan jelas pemikirannya" (hlm. 1). Keterampilan berbahasa memiliki empat komponen utama, antara lain keterampilan berbicara, menyimak, membaca dan menulis. Salah satu keterampilan yang sangat penting untuk dimiliki oleh setiap individu adalah keterampilan menulis. Dari empat aspek tersebut, maka dalam penelitian ini peneliti akan berusaha untuk meningkatkan keterampilan menulis kalimat efektif.

Mengenai penjelasan keterampilan menulis, Dalman (2016) berpendapat, "menulis merupakan suatu kegiatan komunikasi berupa penyampaian pesan (informasi) secara tertulis kepada pihak lain dengan menggunakan bahasa tulis sebagai alat atau medianya" (hlm. 3). Melalui kegiatan menulis yang dilakukan yaitu untuk menyampaikan pesan tertentu dengan baik dan secara tepat. Menulis merupakan sebuah proses kreatif yang menuangkan gagasan dalam bentuk bahasa tulis untuk suatu tujuan. Menulis bukan hanya menuangkan kata ke dalam bentuk tulisan, melainkan mempunyai ide, gagasan, atau ilmu yang dituliskan dengan struktur yang benar. Kegiatan menulis diutamakan dengan memilih diksi (pilihan kata) serta memperhatikan ejaan dan tanda baca. Mengenai kalimat efektif, Soedjito (dalam Nurhayatin \& dkk, 2018) menyatakan bahwa "kalimat efektif merupakan kalimat yang mengungkapkan suatu gagasan yang dapat dipahami secara tepat dengan ciri-ciri lengkap, logis, serasi, padu, hemat, cermat, tidak rancu, dan bervariasi, serta kalimat yang efektif merupakan kalimat yang tidak memiliki subjek ganda". Menulis kalimat efektif yang ditulis oleh siswa akan memberikan pemahaman, menambah ilmu pengetahuan serta proses pembelajaran yang efisien. Keterampilan menulis kalimat efektif pada kelas III terlihat sangat menurun.

Setelah melakukan observasi pada tanggal 4 maret 2021 di SDN 005 Padang Luas, terdapat beberapa masalah yaitu siswa sulit memahami keterampilan menulis kalimat efektif pada pembelajaran tematik, siswa sulit memahami ketika membedakan antara subjek, predikat, objek dan keterangan, kemudian siswa sulit memahami ketika menuliskan contoh dari kalimat efektif. Guru tidak terlihat membahas kembali hasil presentasi siswa pada saat diskusi kelompok, sehingga untuk mengatasi rendahnya kalimat efektif di kelas III sebaiknya pada saat pembelajaran berlangsung siswa membahas kembali yang telah dipresentasikan kemudian kelompok lain memberikan tanggapannya. Ketika guru membentuk siswa dalam kelompok, sebaiknya dibagi menjadi 3-5 orang yang sifatnya heterogen. Guru memberikan lembar tugas siswa secara kelompok dan siswa yang lainnya membuat catatan kecil. Ketika guru membentuk kelompok terlihat siswa mengalami kesulitan ketika berkolaborasi dengan teman satu kelompok, dan saat siswa sudah menjadi beberapa kelompok terlihat siswa bermain-main ketika kegiatan belajar sedang berlangsung. Ketika penulis membaca dan memahami tentang model Think Talk Write (TTW) ternyata model Think Talk Write ini sesuai untuk diterapkan sehingga model ini terlihat bisa mengatasi permasalahan yang telah diuraikan, maka penulis memilih model Think Talk Write (TTW). Model Think Talk Write (TTW) ini adalah kegiatan yang dilakukan siswa untuk menumbuhkembangkan kemampuan pemahaman konsep, kekompakkan dalam berdiskusi dan berkomunikasi dengan siswa yang lainnya. Hal ini diperkuat oleh Shoimin (dalam Armini \& dkk, 2017) 
mengatakan bahwa, "model Think Talk Write (TTW) ini merupakan aktivitas yang dapat dilakukan untuk menumbuhkembangkan kemampuan pemahaman konsep dan komunikasi peserta didik". Model Think Talk Write (TTW) dimulai dengan perencanaan dan tindakan yang cermat mengenai kegiatan pembelajaran yaitu dengan kegiatan berpikir (Think), guru memberikan lembar tugas siswa kepada masing-masing kelompok dan siswa membuat catatan kecil, selanjutnya kegiatan berdiskusi / berbicara (Talk) yaitu siswa berdiskusi dengan teman kelompoknya membahas jawaban yang sesuai dari tes yang diberikan guru dan kegiatan menulis (Write) yaitu siswa menulis jawaban dari tes yang diberikan oleh guru yang telah disepakati dari kelompok masing-masing.

Penerapan model TTW ini dapat memotivasi siswa untuk aktif dalam kegiatan pembelajaran, menambah ilmu pengetahuan siswa dan siswa akan memahami materi yang telah disampaikan. Adapun tujuan penelitian tindakan kelas ini dilakukan sebagai berikut, untuk mengetahui perencanaan pembelajaran dengan penerapan model Think Talk Write (TTW) untuk meningkatkan keterampilan menulis kalimat efektif pada pembelajaran tematik siswa Sekolah Dasar, untuk mengetahui pelaksanaan pembelajaran dengan penerapan model Think Talk Write (TTW) untuk meningkatkan keterampilan menulis kalimat efektif pada pembelajaran tematik siswa Sekolah Dasar, untuk mengetahui peningkatan pembelajaran dengan penerapan model Think Talk Write (TTW) untuk meningkatkan keterampilan menulis kalimat efektif pada pembelajaran tematik siswa Sekolah Dasar . Penelitian yang akan dilakukan ini diharapkan dapat memberikan beberapa manfaat, yaitu bagi siswa Melalui pelaksanaan penelitian ini dapat meningkatkan proses pembelajaran keterampilan menulis kalimat efektif dengan menerapkan model Think Talk Write di kelas III, kemudian bagi guru, melalui proses pembelajaran guru dapat meningkatkan kemampuan untuk menciptakan proses pembelajaran yang efektif dan efesien dengan penerapan model Think Talk Write.

\section{Metode}

Waktu penelitian ini dilaksanakan Juni 2021 pada Semester Genap atau Semester II tahun ajaran 2021/2022. Penelitian tindakan kelas ini yang menjadi subjek penelitian adalah siswa di kelas III Sekolah Dasar Negeri 005 Padang Luas tahun ajaran 2021/2022 dengan jumlah sebanyak 17 siswa dengan jumlah lakilaki 9 siswa dan perempuan berjumlah 8 siswa. Penelitian yang diterapkan oleh peneliti adalah penelitian tindakan kelas. Arikunto, dkk (dalam Ananda, 2017) menyatakan bahwa, "Penelitian Tindakan Kelas (PTK) adalah penelitian tindakan (action research) yang dilakukan dengan tujuan memperbaiki mutu pratik pembelajaran di kelasnya". Penelitian tindakan kelas disebut dengan istilah classroom action research, Arikunto (dalam Aprinawati, 2017) menyatakan bahwa "tujuan utama Penelitian Tindakan Kelas memperbaiki berbagai persoalan nyata dan praktis dalam peningkatan mutu pembelajaran di kelas yang dialami langsung dalam interaksi antara guru dengan siswa yang sedang belajar". (Arikunto, 2016) menyatakan bahwa, Penelitian tindakan kelas merupakan rangkaian tiga buah kata yang masing-masing dapat dijelaskan sebagai berikut:

1) Penelitian menunjukkan pada suatu kegiatan mencermati suatu objek dengan menggunakan cara dan aturan metodologi tertentu untuk memperoleh data atau informasi yang bermanfaat dalam meningkatkan mutu suatu hal yang menarik minat dan penting bagi peneliti. 2) Tindakan menunjukkan pada suatu gerak kegiatan yang dengan sengaja dilakukan dengan tujuan tertentu. Dalam hal ini, gerak kegiatan adalah adanya siklus yang terjadi secara berulang untuk siswa yang dikenai suatu tindakan. 3) Kelas dalam hal ini tidak terikat pada pengertian ruang kelas, tetapi makna yang lain. Seperti sudah lama dikenal sejak zamannya, pendidik Johann Amos Comenius pada abad ke 18, yang dimaksud dengan "kelas" dalam konsep pendidikan dan pengajaran adalah sekelompok peserta didik yang dalam waktu yang sama, belajar hal yang sama dari pendidik yang sama pula (hlm. 2). 
Hal yang dimaksud dengan "kelas" dalam PTK adalah sekelompok peserta didik yang dalam waktu yang sama, belajar hal yang sama dari pendidik yang sama pula. Istilah PTK digunakan untuk guru yang berniat meningkatkan kualitas pembelajarannya melalui pemberian tindakan kepada siswa karena memang yang belajar dalam kelas adalah siswa. Adapun Prosedur tindakan kelas ini terbagi ke dalam empat tahapan tindakan, yaitu Tahap Perencanaan (Planning), Tahap Pelaksanaan (Acting), Tahap Pengamatan (Observing), dan Refleksi (Reflecting).

a. Tahap Perencanaan (Planning)

$$
\text { Arikunto \& dkk, }
$$
mengemukakan bahwa, "perencanaan adalah langkah yang dilakukan oleh guru ketika akan memulai tindakannya" (hlm. 194). Dalam perencanaan peneliti akan menggambarkan semua yang akan dilakukan dalam pelaksanaan penelitian. Dalam pelaksanaan penelitian ini, maka perencanaan pembelajaran sebagai berikut:

1) Menyediakan perangkat pembelajaran yang terdiri dari silabus, RPP, lembar tugas siswa, lembar observasi aktivitas guru dan lembar observasi aktivitas siswa.

2) Membuat skenario pembelajaran tentang materi yang akan diajarkan dengan menjelaskan pembelajaran kalimat efektif dengan penerapkan model pembelajaran Think Talk Write (TTW).

3) Menyusun dan mempersiapkan lembar tugas siswa yaitu berupa teks kemudian tes kelompok dan tes individu yang terkait dengan materi pembelajaran.

4) Menuliskan catatan harian selama proses kegiatan pembelajaran.

b. Tahap Pelaksanaan (Acting)

Arikunto \& dkk (2016) memaparkan secara rinci hal-hal yang harus diperhatikan guru antara lain: "1) apakah ada kesesuaian antara pelaksanaan dengan perencanaan, 2) apakah proses tindakan yang dilakukan pada siswa cukup lancar, 3) bagaimanakah situasi proses tindakan apakah siswa-siswa melaksanakan dengan bersemangat, 4) bagaimanakah hasil keseluruhan dari tindakan itu" (hlm 16).
Dalam pelaksanaan tindakan ini dilakukan untuk meningkatkan nilai siswa pada proses keterampilan menulis kalimat efektif dan pemahaman siswa menulis kalimat efektif pada siswa kelas III. Dalam pelaksanaan penelitian tindakan kelas ini dirancang dalam dua siklus. Setiap siklus dua kali pertemuan. Pelaksanaan tindakan ini disesuaikan dengan RPP yang telah disusun sebelumnya. Langkah-langkah pelaksanaan tindakan atau kegiatan pembelajaran ini terdiri atas tiga tahap yaitu kegiatan awal, kegiatan inti, kegiatan akhir.

c. Tahap Pengamatan (Observing)

Arikunto \& dkk (2016) menyatakan bahwa, "pengamatan adalah proses mencermati jalannya pelaksanaan tindakan" (hlm. 18). Pengamatan dilakukan untuk mendapatkan data selama proses pembelajaran berlangsung. Pengamatan dilaksanakan untuk mengetahui adanya kesesuaian antara perencanaan, pelaksanaan tindakan dan untuk mengetahui sejauhmana tindakan dapat menghasilkan perubahan sesuai dengan rancangan yang sudah disusun. Pengamatan dilakukan oleh guru kelas III SDN 005 Padang Luas dan rekan sejawat untuk mengetahui peningkatan nilai dan pemahaman siswa pada pembelajaran keterampilan menulis kalimat efektif pada siswa kelas III, kegiatan yang dinilai pada lembar pengamatan adalah:

1) Mengamati aktivitas guru dalam proses pembelajaran yang sedang berlangsung yang dinilai oleh guru kelas III dengan penerapan model Think Talk Write dengan menggunakan lembar observasi aktivitas guru.

2) Mengamati aktivitas siswa dalam proses pembelajaran yang sedang berlangsung yang dinilai oleh teman sejawat dengan penerapan model Think Talk Write dengan menggunakan lembar observasi aktivitas siswa.

\section{d. Refleksi (Reflecting)}

Arikunto \& dkk (2016) berpendapat bahwa, "refleksi atau dikenal dengan peristiwa perenungan adalah langkah mengingat kembali kegiatan yang sudah lampau yang dilakukan oleh guru maupun siswa" (hlm. 146). Refleksi pada penelitian ini yaitu analisis hasil observasi dan hasil tes keterampilan menulis kalimat efektif. Refleksi dilaksanakan segera setelah tahap implementasi atau tindakan sudah selesai. Tujuan dari refleksi ini adalah untuk mengetahui keberhasilan dari proses 
pembelajaran keterampilan menulis kalimat efektif dengan penerapan Model Think Talk Write. Mengenai tahap ini peneliti, guru dan teman sejawat mendiskusikan hasil yang meliputi kelebihan dan kekurangan pada proses pembelajaran. Hasil refleksi ini akan digunakan sebagai perbaikan dalam pelaksanaan siklus berikutnya.

Instrumen Penilaian, Arikunto, (2013) menyatakan bahwa, "instrumen penelitian adalah alat atau fasilitas yang dilakukan oleh peneliti dalam mengumpulkan data agar pekerjaannya lebih mudah dan hasilnya lebih baik, dalam arti lebih cermat, lengkap, dan sistematis sehingga lebih mudah diolah" (hlm. 203). Pada penelitian ini menggunakan dua jenis instrumen penilaian yaitu tes evaluasi keterampilan menulis kalimat efektif dan lembar observasi aktivitas guru dan siswa dalam pelaksanaan proses pembelajaran.

1. Tes evaluasi keterampilan menulis kalimat efektif

Tes ini akan dilakukan untuk mengukur tingkat pengetahuan siswa terhadap keterampilan menulis kalimat efektif.. Tes ini akan dilakukan dengan cara siswa membaca teks sesuai dengan materi pembelajaran, selanjutnya siswa di tes secara tertulis dengan mengajukan soal-soal yang berhubungan dengan isi teks tersebut. Adapun kisi-kisi soal tes nya dapat dilihat dilampiran.

2. Lembar observasi aktivitas guru dan siswa dalam pelaksanaan proses pembelajaran.

Lembar observasi dalam pelaksanaan pembelajaran digunakan untuk mengamati aktivitas guru dalam tahapan pembelajaran dengan penerapan model Think Talk Write, yang di nilai oleh guru kelas III, selama proses pembelajaran dan Lembar observasi aktivitas siswa dalam tahapan pembelajaran dengan penerapan model Think Talk Write, yang di nilai oleh teman sejawat. Lembar observasi ini digunakan untuk mengetahui kesesuaian Rencana Pelaksanaan Pembelajaran (RPP) yang dibuat oleh peneliti dengan pelaksanaan pembelajaran yang dilakukan oleh guru dengan menggunakan tanda ceklis $(\sqrt{ })$ jika hal yang diamati sudah muncul.

Teknik Analisis Data, Analisis data dilakukan sejak awal penelitian. Pada setiap aspek kegiatan penelitian. Peneliti juga dapat langsung menganalisis apa yang diamati, situasi dan suasana kelas atau lapangan, hubungan guru dengan siswa juga teman yang lainnya, Iskandar, (2015) menyatakan bahwa:

Teknik analisis data dalam penelitian tindakan kelas tergolong sederhana karena hanya berupa persentase. Namun demikian, PTK juga mengkolaborasikan dengan data kualitatif yang diperoleh selama proses pembelajaran berlangsung. Oleh karena itu teknik analisis data yang tepat dalam penelitian tindakan kelas yaitu teknik deskriptif persentase. Teknik ini digunakan untuk mendeskripsikan data kuantitatif dan kualitatif yang diinterpretasikan dalam bentuk uraian (hlm. 72).

\section{Hasil dan Pembahasan}

Proses penelitian dilakukan dengan Pengamatan dilaksanakan untuk mengetahui adanya kesesuaian antara perencanaan, pelaksanaan tindakan dan untuk mengetahui sejauh mana tindakan dapat menghasilkan perubahan sesuai dengan rancangan yang sudah disusun. Berdasarkan hasil observasi terhadap guru, setiap aspek dalam lembar observasi diberi tanda "ya" atau "tidak". Hasil analisis dari lembaran pengamatan aktivitas guru dan aktivitas siswa secara umum pada proses pembelajaran sudah terlaksana dengan baik, walaupun dalam proses pembelajaran terkadang ada langkah-langkah yang belum terlaksana secara optimal dan hasil observasi terhadap proses pembelajaran pada siklus I pertemuan pertama dan pertemuan kedua, diketahui proses pembelajaran berlangsung dengan lancar dan siswa bersemangat mengikuti proses pembelajaran secara kelompok. 
Jurnal Edumaspul, 5 (2), Year 2021- 255

(Erlina Sari, Iis Aprinawati, Rizki Ananda)

Adapun analisis tulisan yang diwakilkan dari siswa pada siklus I dengan kategori baik sekali yaitu sebagai berikut:

\section{a) Kategori baik sekali}

Berdasarkan hasil keterampilan menulis kalimat efektif pada siklus I, siswa menjawab tes individu dengan materi cuaca dan kehidupan manusia pada buku siswa tema 5, kemudian siswa memperoleh nilai dengan kategori baik sekali dengan nomor responden 14 dengan nilai 80 . Adapun hasil tulisan siswa dengan inisial DFI dapat dilihat sebagai berikut:

Gambar 1

Contoh tulisan siswa pada tes individu

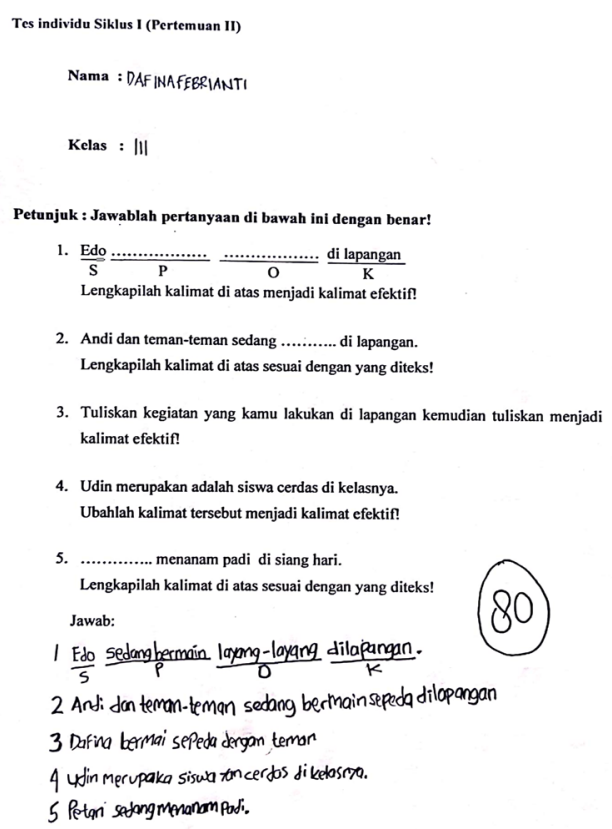


Jurnal Edumaspul, 5 (2), Year 2021- 256

(Erlina Sari, Iis Aprinawati, Rizki Ananda)

Tabel 1

Penjelasan dari setiap jawaban yang ditulis oleh siswa

\begin{tabular}{|c|c|c|}
\hline No & $\begin{array}{c}\text { Indikator } \\
\text { yang dinilai }\end{array}$ & Deskripsi \\
\hline \multirow[t]{4}{*}{1.} & $\begin{array}{l}\text { Aspek } \\
\text { kesatuan }\end{array}$ & $\begin{array}{l}\text { siswa mendapatkan skor } 25 \text {, karena siswa menulis jawaban dengan mengetahui unsur subjek, predikat, objek dan } \\
\text { keterangan. }\end{array}$ \\
\hline & $\begin{array}{l}\text { Aspek } \\
\text { kehematan }\end{array}$ & $\begin{array}{l}\text { Siswa mendapatkan skor } 25 \text {, karena siswa menulis jawaban dengan jumlah kata yang digunakan dengan makna } \\
\text { yang mudah dipahami oleh orang lain dan siswa tidak menulis makna yang sama pada kalimat. }\end{array}$ \\
\hline & $\begin{array}{l}\text { Aspek } \\
\text { kelogisan }\end{array}$ & $\begin{array}{l}\text { siswa mendapatkan skor } 25 \text {, karena siswa menulis jawaban dengan kalimat yang logis dan penulisannya sesuai } \\
\text { dengan ejaan yang benar. }\end{array}$ \\
\hline & $\begin{array}{l}\text { Aspek kaidah } \\
\text { tata Bahasa }\end{array}$ & $\begin{array}{l}\text { siswa mendapatkan skor } 25 \text {, karena siswa menulis huruf kapital di awal kalimat serta menulis tanda baca titik (.) } \\
\text { di akhir kalimat. }\end{array}$ \\
\hline \multirow[t]{4}{*}{2.} & $\begin{array}{l}\text { Aspek } \\
\text { kesatuan }\end{array}$ & $\begin{array}{l}\text { siswa mendapatkan skor 25, karena siswa menulis jawaban dengan mengetahui unsur subjek, predikat, objek dan } \\
\text { keterangan. }\end{array}$ \\
\hline & $\begin{array}{l}\text { Aspek } \\
\text { kehematan }\end{array}$ & $\begin{array}{l}\text { siswa mendapatkan skor } 25 \text {, karena siswa menulis jawaban dengan jumlah kata yang digunakan dengan makna } \\
\text { yang mudah dipahami oleh orang lain dan siswa tidak menulis makna yang sama pada kalimat. }\end{array}$ \\
\hline & $\begin{array}{l}\text { Aspek } \\
\text { kelogisan }\end{array}$ & $\begin{array}{l}\text { siswa mendapatkan skor } 25 \text {, karena siswa menulis jawaban dengan kalimat yang logis dan penulisannya sesuai } \\
\text { dengan ejaan yang benar. }\end{array}$ \\
\hline & $\begin{array}{l}\text { Aspek kaidah } \\
\text { tata Bahasa }\end{array}$ & $\begin{array}{l}\text { siswa mendapatkan skor } 18 \text {, karena siswa menulis huruf kapital di awal kalimat tetapi tidak menulis tanda baca } \\
\text { titik (.) di akhir kalimat terlihat pada saat guru memeriksa jawaban siswa tersebut. }\end{array}$ \\
\hline \multirow[t]{4}{*}{3.} & $\begin{array}{l}\text { Aspek } \\
\text { kesatuan }\end{array}$ & $\begin{array}{l}\text { siswa mendapatkan skor } 15 \text {, karena Siswa menulis jawaban dengan mengetahui unsur subjek, predikat dan objek } \\
\text { tetapi siswa tidak menulis unsur keterangan. }\end{array}$ \\
\hline & $\begin{array}{l}\text { Aspek } \\
\text { kehematan }\end{array}$ & $\begin{array}{l}\text { siswa mendapatkan skor } 18 \text {, karena siswa menulis jawaban dengan jumlah kata yang digunakan dengan makna } \\
\text { yang sedikit dipahami oleh orang lain dan siswa tidak menulis makna yang sama pada kalimat. }\end{array}$ \\
\hline & $\begin{array}{l}\text { Aspek } \\
\text { kelogisan }\end{array}$ & $\begin{array}{l}\text { siswa mendapatkan skor } 15 \text {, karena Siswa menulis jawaban dengan kalimat yang logis namun dalam } \\
\text { penulisannya kurang sesuai dengan ejaan yang benar. }\end{array}$ \\
\hline & $\begin{array}{l}\text { Aspek kaidah } \\
\text { tata Bahasa }\end{array}$ & $\begin{array}{l}\text { siswa mendapatkan skor } 18 \text {, karena siswa menulis huruf kapital di awal kalimat tetapi tidak menulis tanda baca } \\
\text { titik (.) di akhir kalimat. }\end{array}$ \\
\hline \multirow[t]{4}{*}{4.} & $\begin{array}{l}\text { Aspek } \\
\text { kesatuan }\end{array}$ & $\begin{array}{l}\text { siswa mendapatkan skor 25, karena siswa menulis jawaban dengan mengetahui unsur subjek, predikat, objek dan } \\
\text { keterangan }\end{array}$ \\
\hline & $\begin{array}{l}\text { Aspek } \\
\text { kehematan }\end{array}$ & $\begin{array}{l}\text { siswa mendapatkan skor 18, karena siswa menulis jawaban dengan jumlah kata yang digunakan dengan makna } \\
\text { yang sedikit dipahami oleh orang lain dan siswa tidak menulis makna yang sama }\end{array}$ \\
\hline & $\begin{array}{l}\text { Aspek } \\
\text { kelogisan }\end{array}$ & $\begin{array}{l}\text { siswa mendapatkan skor } 15 \text {, karena Siswa menulis jawaban dengan kalimat yang logis namun dalam } \\
\text { penulisannya kurang sesuai dengan ejaan yang benar }\end{array}$ \\
\hline & $\begin{array}{l}\text { Aspek kaidah } \\
\text { tata Bahasa }\end{array}$ & $\begin{array}{l}\text { siswa mendapatkan skor 5, karena siswa tidak menulis huruf kapital di awal kalimat tetapi menuli tanda baca titik } \\
\text { (.) di akhir kalimat }\end{array}$ \\
\hline \multirow[t]{4}{*}{5.} & $\begin{array}{l}\text { Aspek } \\
\text { kesatuan }\end{array}$ & $\begin{array}{l}\text { siswa mendapatkan skor 15, karena Siswa menulis jawaban dengan mengetahui unsur subjek, predikat dan objek } \\
\text { tetapi siswa tidak menulis unsur keterangan. }\end{array}$ \\
\hline & $\begin{array}{l}\text { Aspek } \\
\text { kehematan }\end{array}$ & $\begin{array}{l}\text { siswa mendapatkan skor 18, karena siswa menulis jawaban dengan jumlah kata yang digunakan dengan makna } \\
\text { yang sedikit dipahami oleh orang lain dan siswa tidak menulis makna yang sama pada kalimat. }\end{array}$ \\
\hline & $\begin{array}{l}\text { Aspek } \\
\text { kelogisan }\end{array}$ & $\begin{array}{l}\text { siswa mendapatkan skor } 15 \text {, karena Siswa menulis jawaban dengan kalimat yang logis namun dalam } \\
\text { penulisannya kurang sesuai dengan ejaan yang benar. }\end{array}$ \\
\hline & $\begin{array}{l}\text { Aspek kaidah } \\
\text { tata Bahasa }\end{array}$ & $\begin{array}{l}\text { siswa mendapatkan skor } 15 \text {, karena Siswa menulis jawaban dengan kalimat yang logis namun dalam } \\
\text { penulisannya kurang sesuai dengan ejaan yang benar. }\end{array}$ \\
\hline
\end{tabular}


Adapun nilai siswa pada siklus I dalam kategori menjadi kurang, cukup, baik, baik sekali.

Tabel 2

Kategori nilai keterampilan menulis kalimat efektif

\begin{tabular}{|c|c|c|c|}
\hline No & kategori & Rentang nilai & $\begin{array}{c}\text { Jumlah } \\
\text { siswa }\end{array}$ \\
\hline 1. & $\begin{array}{c}\text { Baik } \\
\text { sekali }\end{array}$ & $80-100$ & 1 \\
\hline 2. & Baik & $65-79$ & 7 \\
\hline 3. & Cukup & $50-64$ & 9 \\
\hline 4. & Kurang & $<49$ & - \\
\hline
\end{tabular}

Uraian tabel di atas menunjukkan bahwa siswa yang memperoleh nilai baik sekali (80-100) sebanyak 1 siswa, nilai baik (65-79) sebanyak 7 siswa dan nilai cukup (5064) sebanyak 9 siswa. Hasil tindakan pada siklus I terlihat keterampilan menulis kalimat efektif sudah meningkat, berikut tabel hasil tes dan rata-rata keterampilan menulis kalimat efektif pada siklus I.

Tabel 3

Hasil tes keterampilan menulis kalimat efektif

\begin{tabular}{|c|c|c|c|}
\hline No & Kategori & $\begin{array}{c}\text { Jumlah } \\
\text { siswa }\end{array}$ & $\begin{array}{c}\text { Persentase } \\
(\%)\end{array}$ \\
\hline 1. & Tuntas & 8 & $47,05 \%$ \\
\hline 2. & $\begin{array}{c}\text { Tidak } \\
\text { tuntas }\end{array}$ & 9 & $52,94 \%$ \\
\hline 3. & Rata-rata & \multicolumn{2}{|c|}{$68,47 \%$} \\
\hline
\end{tabular}

Berdasarkan tabel di atas jumlah siswa yang tuntas pada siklus I adalah 8 siswa dan yang tidak tuntas adalah 9 siswa. Persentase ketuntasan rata-rata dan keterampilan menulis kalimat efektif pada siswa belum mencapai kriteria ketuntasan minimal (KKM) yang ditetapkan yaitu 65, sedangkan persentase rata-rata kelas siswa juga belum mencukupi. Oleh karena itu, peneliti akan melakukan perbaikan pada pertemuan selanjutnya yang dilaksanakan pada siklus II.

Hasil analisis dari lembaran pengamatan aktivitas guru dan aktivitas siswa pada proses pembelajaran diketahui bahwa proses pembelajaran sudah terlaksana dengan baik. Siswa terlihat bersemangat dan senang pada saat mengikuti proses pembelajaran. Berdasarkan hasil observasi terhadap proses pembelajaran pada siklus II pada pertemuan pertama dan pertemuan kedua, diketahui bahwa siswa sudah mengikuti pembelajaran dengan baik, aktif, siswa sudah memahami menulis kalimat efektif dan siswa juga sudah memahami bahwa pada saat menulis kalimat yang mempunyai makna yang sama, maka siswa hanya menulis salah satu dari makna tersebut.

Adapun analisis tulisan yang diwakilkan dari siswa pada siklus II dengan kategori baik sekali yaitu sebagai berikut:

\section{a) Kategori baik sekali}

Berdasarkan hasil keterampilan menulis kalimat efektif pada siklus II, siswa menulis jawaban tes individu dengan materi menjaga lingkungan agar tetap bersih pada buku siswa tema 5, kemudian siswa memperoleh nilai dengan kategori baik sekali berjumlah 8 siswa dengan nomor responden $2,3,4,5,8,9,12$, 14. Salah satu kategori baik akan diwakilkan dengan siswa nomor responden 12 dengan nilai 84. Adapun hasil tulisan siswa dengan inisial RDZ sebagai berikut: 
Jurnal Edumaspul, 5 (2), Year 2021- 258

(Erlina Sari, Iis Aprinawati, Rizki Ananda)

Gambar 2

Contoh tulisan siswa pada tes individu

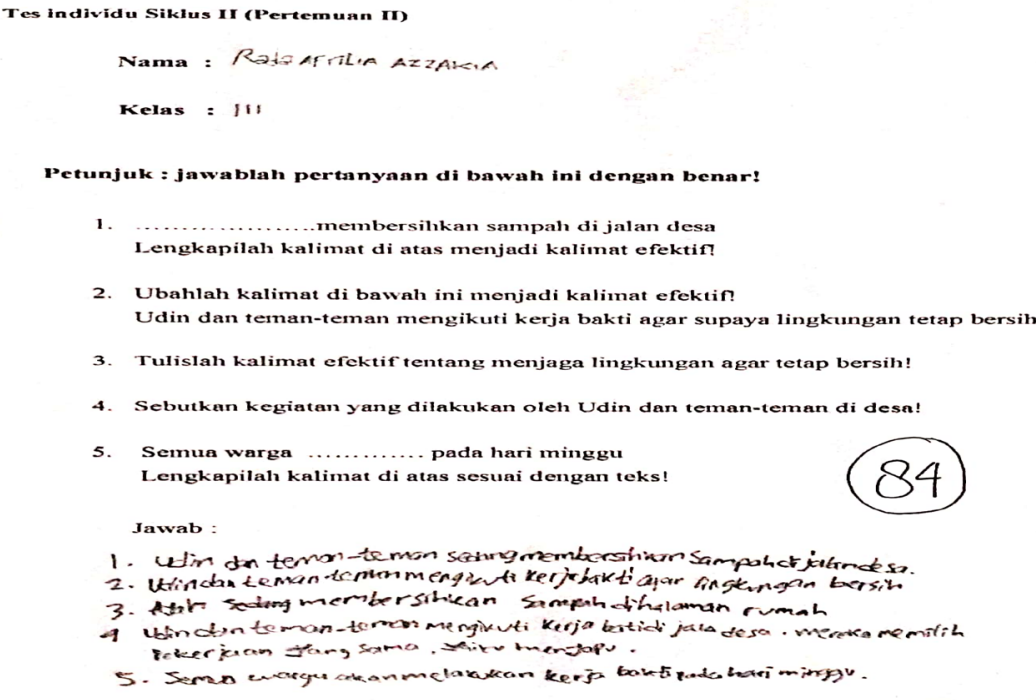

Tabel 4

penjelasan dari setiap jawaban yang ditulis oleh siswa

\begin{tabular}{|c|l|l|}
\hline No & Indikator yang dinilai & \multicolumn{1}{|c|}{ Deskripsi } \\
\hline 1. & Aspek kesatuan & $\begin{array}{l}\text { siswa mendapatkan skor 25, karena siswa } \\
\text { menulis jawaban dengan mengetahui unsur } \\
\text { subjek, predikat, objek dan keterangan. }\end{array}$ \\
\hline & Aspek kehematan & $\begin{array}{l}\text { siswa mendapatkan skor 25, karena siswa } \\
\text { menulis jawaban dengan jumlah kata yang } \\
\text { digunakan dengan makna yang mudah dipahami } \\
\text { oleh orang lain dan siswa tidak menulis makna } \\
\text { yang sama pada kalimat }\end{array}$ \\
\hline & Aspek kelogisan & $\begin{array}{l}\text { siswa mendapatkan skor 25, karena siswa } \\
\text { menulis jawaban dengan kalimat yang logis } \\
\text { dan penulisannya sesuai dengan ejaan yang } \\
\text { benar }\end{array}$ \\
\hline Aspek kaidah tata & $\begin{array}{l}\text { siswa mendapatkan skor 5, karena siswa tidak } \\
\text { menulis huruf kapital di awal kalimat tetapi } \\
\text { menuli tanda baca titik (.) diakhir kalimat. }\end{array}$ \\
\hline Aspek kesatuan & $\begin{array}{l}\text { siswa mendapatkan skor 25, karena siswa } \\
\text { menulis jawaban dengan mengetahui unsur } \\
\text { subjek, predikat, objek dan keterangan. }\end{array}$ \\
\hline & $\begin{array}{l}\text { siswa mendapatkan skor 18, karena siswa } \\
\text { menulis jawaban dengan jumlah kata yang } \\
\text { digunakan dengan makna yang sedikit dipahami } \\
\text { oleh orang lain dan siswa tidak menulis makna } \\
\text { yang sama pada kalimat. }\end{array}$ \\
\hline Aspek kehematan & $\begin{array}{l}\text { siswa mendapatkan skor 25, karena Siswa } \\
\text { menulis jawaban dengan kalimat yang logis } \\
\text { dan penulisannya sesuai dengan ejaan yang } \\
\text { benar. }\end{array}$ \\
\hline
\end{tabular}


Jurnal Edumaspul, 5 (2), Year 2021- 259

(Erlina Sari, Iis Aprinawati, Rizki Ananda)

\begin{tabular}{|c|c|c|}
\hline & $\begin{array}{l}\text { Aspek kaidah tata } \\
\text { Bahasa }\end{array}$ & $\begin{array}{l}\text { siswa mendapatkan skor } 18, \text { karena siswa } \\
\text { menulis huruf kapital di awal kalimat tetapi tidak } \\
\text { menulis tanda baca titik (.) di akhir kalimat. }\end{array}$ \\
\hline \multirow[t]{4}{*}{3.} & Aspek kesatuan & $\begin{array}{l}\text { siswa mendapatkan skor 25, karena siswa } \\
\text { menulis jawaban dengan mengetahui unsur } \\
\text { subjek, predikat, objek dan keterangan. }\end{array}$ \\
\hline & Aspek kehematan & $\begin{array}{l}\text { siswa mendapatkan skor 18, karena siswa } \\
\text { menulis jawaban dengan jumlah kata yang } \\
\text { digunakan dengan makna yang sedikit dipahami } \\
\text { oleh orang lain dan siswa tidak menulis makna } \\
\text { yang sama pada kalimat }\end{array}$ \\
\hline & Aspek kelogisan & $\begin{array}{l}\text { siswa mendapatkan skor } 15, \text { karena siswa } \\
\text { menulis jawaban dengan kalimat yang logis } \\
\text { namun dalam penulisannya kurang sesuai } \\
\text { dengan ejaan yang benar }\end{array}$ \\
\hline & $\begin{array}{l}\text { Aspek kaidah tata } \\
\text { Bahasa }\end{array}$ & $\begin{array}{l}\text { siswa mendapatkan skor 18, karena siswa } \\
\text { menulis huruf kapital di awal kalimat tetapi tidak } \\
\text { menulis tanda baca titik (.) di akhir kalimat. }\end{array}$ \\
\hline \multirow[t]{4}{*}{4.} & Aspek kesatuan & $\begin{array}{l}\text { siswa mendapatkan skor 25, karena siswa } \\
\text { menulis jawaban dengan mengetahui unsur } \\
\text { subjek, predikat, objek dan keterangan. }\end{array}$ \\
\hline & Aspek kehematan & $\begin{array}{l}\text { siswa mendapatkan skor 25, karena siswa } \\
\text { menulis jawaban dengan jumlah kata yang } \\
\text { digunakan dengan makna yang mudah dipahami } \\
\text { oleh orang lain dan siswa tidak menulis makna } \\
\text { yang sama pada kalimat. }\end{array}$ \\
\hline & Aspek kelogisan & $\begin{array}{l}\text { siswa mendapatkan skor 15, karena } \\
\text { menulis jawaban dengan kalimat yang } \\
\text { namun dogis } \\
\text { dengan ejaan yang benar. }\end{array}$ \\
\hline & $\begin{array}{l}\text { Aspek kaidah tata } \\
\text { Bahasa }\end{array}$ & $\begin{array}{l}\text { siswa mendapatkan skor 25, karena siswa } \\
\text { menulis huruf kapital di awal kalimat serta } \\
\text { menulis tanda baca titik (.) di akhir kalimat. }\end{array}$ \\
\hline \multirow[t]{4}{*}{5.} & Aspek kesatuan & $\begin{array}{l}\text { siswa mendapatkan skor 25, karena siswa } \\
\text { menulis jawaban dengan mengetahui unsur } \\
\text { subjek, predikat, objek dan keterangan. }\end{array}$ \\
\hline & Aspek kehematan & $\begin{array}{l}\text { siswa mendapatkan skor 25, karena siswa } \\
\text { menulis jawaban dengan jumlah kata yang } \\
\text { digunakan dengan makna yang mudah dipahami } \\
\text { oleh orang lain dan siswa tidak menulis makna } \\
\text { yang sama pada kalimat }\end{array}$ \\
\hline & Aspek kelogisan & $\begin{array}{l}\text { siswa mendapatkan skor } 15, \text { karena Siswa } \\
\text { menulis jawaban dengan kalimat yang logis } \\
\text { namun dalam penulisannya kurang sesuai } \\
\text { dengan ejaan yang benar. }\end{array}$ \\
\hline & $\begin{array}{l}\text { Aspek kaidah tata } \\
\text { Bahasa }\end{array}$ & $\begin{array}{l}\text { siswa mendapatkan skor 25, karena siswa } \\
\text { menulis huruf kapital di awal kalimat serta } \\
\text { menulis tanda baca titik (.) di akhir kalimat. }\end{array}$ \\
\hline
\end{tabular}


Nilai siswa pada siklus II dalam kategori menjadi kurang, cukup, baik, baik sekali dapat dilihat pada tabel di bawah ini:

Tabel 5

Kategori nilai keterampilan menulis kalimat efektif

\begin{tabular}{|c|c|c|c|}
\hline No & kategori & $\begin{array}{c}\text { Rentang } \\
\text { nilai }\end{array}$ & $\begin{array}{c}\text { Jumlah } \\
\text { siswa }\end{array}$ \\
\hline 1. & Baik sekali & $80-100$ & 8 \\
\hline 2. & Baik & $65-79$ & 6 \\
\hline 3. & Cukup & $50-64$ & 3 \\
\hline 4. & Kurang & $<49$ & - \\
\hline
\end{tabular}

Berdasarkan data di atas, keterampilan menulis kalimat efektif pada siswa kelas III SD Negeri 005 Padang Luas sudah baik. Pelaksanaan proses pembelajaran pada siklus II pada pertemuan kedua secara umum sudah baik berdasarkan dari hasil tes, dapat diketahui bahwa keterampilan menulis kalimat efektif mengalami peningkatan, terlihat pada tabel di bawah ini:

Tabel 6

Hasil tes keterampilan menulis kalimat efektif

\begin{tabular}{|l|c|c|c|}
\hline No & Kategori & $\begin{array}{c}\text { Jumlah } \\
\text { siswa }\end{array}$ & $\begin{array}{c}\text { Persentase } \\
\text { (\%) }\end{array}$ \\
\hline 1. & Tuntas & 14 & $82,35 \%$ \\
\hline 2. & $\begin{array}{c}\text { Tidak } \\
\text { tuntas }\end{array}$ & 3 & $17,64 \%$ \\
\hline 3. & Rata-rata & \multicolumn{2}{|c|}{$76,23 \%$} \\
\hline
\end{tabular}

Tabel di atas dengan jumlah siswa yang tuntas 14 siswa dan yang tidak tuntas berjumlah 3 siswa dan ketuntasan secara klasikal sudah di atas $\mathrm{KKM} \geq 75 \%$, maka secara klasikal sudah dikatakan tuntas, sehingga peneliti dan guru kelas sependapat untuk menghentikan perbaikan pembelajaran dan penelitian ini hanya sampai siklus II atau tidak dilanjutkan ke siklus berikutnya. Peneliti menyampaikan kepada guru kelas bahwa dengan penerapan model Think Talk Write (TTW) dapat meningkatkan keterampilan menulis kalimat efektif pada siswa kelas III.

Perbandingan hasil keterampilan menulis kalimat efektif pada siswa kelas III SD Negeri 005 Padang Luas dari siklus I dan siklus II dengan penerapan model Think Talk Write (TTW) dapat dilihat pada grafik berikut:

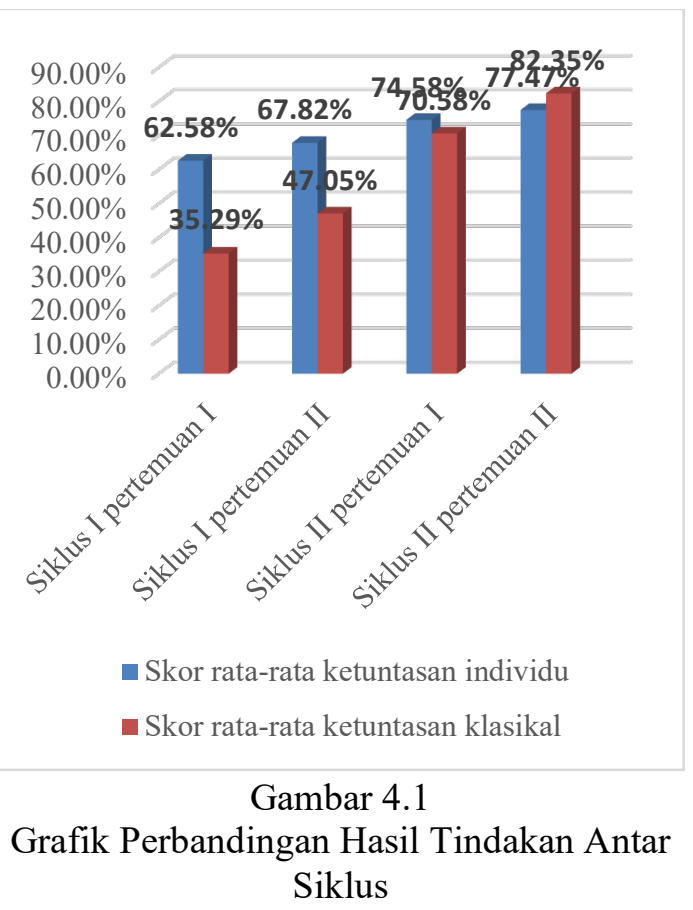

Berdasarkan rekapitulasi yang dipaparkan pada grafik di atas, diketahui perbandingan hasil tindakan antar siklus, maka keterampilan menulis kalimat efektif dengan penerapan model Think Talk Write dapat meningkat dilihat dari siklus I hingga siklus II, oleh karena itu peneltian ini tidak dilanjutkan pada siklus berikutnya.

\section{Simpulan}

Penelitian tindakan kelas (PTK) pada siswa kelas III SD Negeri 005 Padang Luas dilaksanakan dalam dua siklus, setiap siklus terdiri dari tahap perencanaan (planning), tahap pelaksanaan (acting), tahap pengamatan (observing), dan refleksi (reflecting). Berdasarkan penelitian yang telah dilaksanakan maka dapat disimpulkan bahwa perencanaan pada siklus I masih terdapat banyak kekurangan seperti peneliti belum melaksanakan proses dengan baik, bahkan keterampilan menulis kalimat efektif pada siklus I masih tergolong rendah, namun setelah dilakukan refleksi pada siklus I, yaitu perbaikan-perbaikan dari kekurangan yang terjadi pada siklus I maka akan diperbaiki pada siklus II. Begitu dilakukan perbaikan pada siklus II, proses pembelajaran dilaksanakan dengan baik dan sudah sesuai dengan yang direncanakan sebelumnya, sehingga terjadi peningkatan dari siklus I dan siklus II. Pelaksanaan proses pembelajaran dengan penerapan model Think Talk Write 
untuk meningkatkan keterampilan menulis kalimat efektif pada pembelajaran tematik pada siklus I proses kegiatan pembelajaran berlangsung dengan baik yang telah dilaksanakan sesuai denga RPP, aktivitas guru dan siswa pada saat proses pembelajaran sudah memenuhi sesuai dengan RPP, walaupun pada siklus I masih terdapat kekurangan yang harus diperbaiki pada siklus II.

Pelaksanaan pada siklus II telah dilaksanakan dengan baik oleh peneliti sebagai guru, yang telah dilaksanakan sesuai dengan RPP, dalam pelaksanaan pembelajaran guru menyampaikan atau menjelaskan kalimat efektif agar siswa mudah untuk menjawab soal yang diberikan oleh guru. peningkatan pembelajaran dengan penerapan model Think Talk Write (TTW) dapat dilihat pada siklus I pertemuan pertama terdapat rata-rata ketuntasan individu $62,58 \%$ dan ketuntasan secara klasikal $35,29 \%$, kemudian dilanjutkan pada siklus I pertemuan kedua dengan rata-rata ketuntasan individu $67,82 \%$ dan ketuntasan secara klasikal $47,05 \%$, karena belum memenuhi kriteria maka dilanjutkan pada siklus II pertemuan pertama dengan rata-rata ketuntasan individu $74,58 \%$ dan ketuntasan secara klasikal 70,58\%, kemudian dilanjutkan pada siklus II pertemuan kedua $77,47 \%$ dan ketuntasan secara klasikal $82,35 \%$, maka terlihat pada siklus I dan siklus II mengalami peningkatan keterampilan menulis kalimat efektif dengan penerapan model Think Talk Write.

\section{Daftar Pustaka}

[1] Ananda, R. (2017). Penerapan Model Kooperatif Tipe Numbered Head Together Untuk Meningkatkan Hasil Belajar IPS Siswa Kelas IV SDN 003 Bangkinang Kota. Jurnal Handayani, 7(1), 46-57.

[2] Apriani, H. (2020). Pengaruh Penguasaan Kalimat Efektif Terhadap Kemampuan Menulis Karangan Narasi Pada Siswa. 02(2), 119-128.

[3] Aprinawati, I. (2017). Penerapan Model Peta Pikiran (Mind Mapping) Untuk Meningkatkan Keterampilan Menulis Karangan Narasi Siswa Kelas Ivb $\mathrm{Sd}$ Negeri 007 Bangkinang. Elementary School
Journal Pgsd Fip Unimed, 7(1), 19-31. https://doi.org/10.24114/esjpgsd.v7i1.6398

[4] Arikunto, \& dkk. (2016). penelitian tindakan kelas. Jakarta: Bumi Aksara.

[5] Dari, S. W., \& dkk. (2017). Keefektifan Kalimat Dalam Teks Eksposisi Siswa Kelas VII MTS Diniyah Pandai Sikek. Pendidikan Bahasa Dan Sastra Indonesia, 6(2), 353-361.

[6] Dewi, Y. (2016). Penerapan Model Pembelajaran Think Talk Write (TTW) Berbantuan Media Gambar Seri Untuk Meningkatkan Keterampilan Menulis Karangan Siswa Kelas III SD. E-Journal PGSD Universitas Pendidikan Ganesha, 4, $1-10$.

[7] Elida, N. (2012). Meningkatkan Komunikasi Matematika Siswa Sekolah Menengah Pertama melalui Pembelajaran Think Talk Write (TTW). Jurnal Infinity, 1 No. 2.

[8] Gissella, M. V. E. (2016). Peningkatan Keterampilan Menulis Karangan Deskripsi Menggunakan Guided Writing Siswa Kelas V SD Negeri Minomartani 6 Ngaglik Sleman. Universitas Negeri Yogyakarta.

[9] Hijria, F. R., \& dkk. (2018). Pengembangan Buku Ajar Bahasa Indonesia Dengan Model Circ Untuk Meningkatkan Keterampilan Literasi Berbahasa Siswa Kelas V SD. Jurnal Kajian Pendidikan Dan Hasil Penelitian, 4(1).

[10] Huda, M. (2013). Model-model Pengajaran dan Pembelajaran. Yogyakarta: Pustaka Pelajar.

[11] Iskandar, D. dan N. (2015). Penelitian Tindakan Kelas dan Publikasinya Untuk Kenaikan Pangkat dan Golongan Guru \& Pedoman Penulisan PTK bagi Mahasiswa. Cilacap:Ihya Media.

[12] Isjoni. (2013). Cooperative Learning: Mengembangkan Kemampuan Belajar Kelompok. Bandung: Alfabeta.

[13] Isnanda, R. (2015). Penggunaan Kalimat Efektif Dalam Karya Ilmiah Siswa: Aplikasi Semantik Studi Kasus Siswa Kelas XI SMK Negeri 2 Lembah Gumanti. Jurnal Gramatika Jurnal Penelitian Bahasa Dan 
Jurnal Edumaspul, 5 (2), Year 2021- 262

(Erlina Sari, Iis Aprinawati, Rizki Ananda)

Sastra Indonesia V1.I2 (174-182) ISSN:

2(2),

174-182.

https://media.neliti.com/media/publications

/80703-ID-peran-pengajaran-sastra-dan-

budaya-dalam.pdf J

[14] Kemendikbud. (2013). Di Panduan Teknis

Penilaian 2013 Madrasah Kurikulum.

Jakarta: Kementerian Pendidikan dan

Kebudayaan.

[15] Kusumaningsih, D., \& dkk. (2013). Terampil Berbahasa Indonesia. Yogyakarta: ANDI.

[16] Lazulfa, I. (2019). Keterampilan Berbahasa: Menulis Karangan Eksposisi. https://doi.org/10.31227/osf.io/3rgyk

[17] Mudjiyanti, R. dan M. (2017). Peningkatan Keterampilan Menulis Cerita Pendek Melalui Metode Penugasan. In Mudjiyanti, Rina: Vol. XVII (Issue November). Universitas Muhammadiyah Purwokerto.

[18] Meiroza, H. T. (2019). Penerapan Model
Pembelajaran Think Talk Write (TTW) Terhadap Keterampilan Menulis Karangan Narasi Siswa Kelas $V$ Sd Negeri 161 Pekanbaru. Jurnal Pajar (Pendidikan Dan Pengajaran), 3(4), 923-933. https://doi.org/10.33578/pjr.v3i4.7422

[19] Mesterianti, M., \& dkk. (2019). Penerapan Model Think Talk Write Untuk Meningkatkan Keterampilan Menulis Kalimat Efektif Pada Siswa Kelas III SDN Sumbersari 1 Kota Malang Janardhana. Edukasi: Jurnal Pendidikan, 17(1), 98.

\section{Profil Penulis}

Nama : Erlina Sari

Tempat \&

Tanggal Lahir : Danau Bingkuang, 03 juli 1998

Program Studi : PGSD

Pekerjaan : - 